\title{
Synthesis of Phosphopeptides
}

\section{II. * O-Phosphorylated Dipeptides of L-Serine}

\author{
GEORG F ÖLSCH
}

Department of Medical Biochemistry, University of Gothenburg, Gothenburg, Sweden

\begin{abstract}
Diphenylphosphoryl and dibenzylphosphoryl chlorides have been used for phosphorylation of six $\mathrm{N}$-carbobenzoxy dipeptide benzyl esters of L-serine with amino acid sequences shown to occur in phosphoproteins. Catalytic hydrogenolysis of the dibenzylphosphoryl derivatives yields pure phosphopeptides, whereas the products obtained from the diphenyl analogs frequently contain partially hydrogenolysed derivatives.
\end{abstract}

$\mathrm{P}$ hosphoproteins and phosphopeptide fractions obtained from phosphoproteins usually have a high content of the two dicarboxylic acids glutamic acid and aspartic acid ${ }^{1-5}$, and several peptides have been isolated after degradation of such proteins in which $\mathrm{O}$-phosphorylated serine residues were bound by peptide linkages to these acids. The peptide O-phosphoryl-L-seryl-Lglutamic acid was isolated from casein as early as $1933^{6-7}$. Also the reverse sequence, Glu-SerP, seems to be present in casein as well as SerP-Asp apart from other sequences, such as Leu-SerP and SerP-SerP ${ }^{8-9}$. The last-mentioned sequence seems to build up a large portion of phosvitin **, whereas, in pepsin, the lone phosphorylserine residue, again, is bound to glutamic acid in the sequence Thr-SerP-Glu ${ }^{10}$. Finally, after acid hydrolysis, the two phosphorus atoms of ovalbumin are found in the fragments Glu-SerP-Ala and Asp-SerP-Glu, of which only the former is dephosphorylated by prostatic phosphatase ${ }^{10}$.

For a more detailed study of the biological and chemical properties of phosphorylated peptides, e.g. their behaviour towards different phosphatases and proteolytic enzymes or their metal binding properties ${ }^{11-17}$, synthetic preparation of these compounds seemed to be of interest. Synthetic preparation also permits considerable structural variations. In previous papers ${ }^{17-21}$, a

* Paper I, see Ref. ${ }^{20}$. Abbreviations and symbols used as previously. The symbol SerP is used for an O-phosphorylserine residue, $-\mathrm{NH} \cdot \mathrm{CH}\left[\mathrm{CH}_{2} \mathrm{OPO}(\mathrm{OH})_{2}\right] \mathrm{CO}-$; $\mathrm{Z}$ for carbobenzoxy, $\mathrm{C}_{6} \mathrm{H}_{5} \mathrm{CH}_{2} \mathrm{OCO}-$; $\mathrm{Bz}$ for benzyl, $\mathrm{C}_{6} \mathrm{H}_{5} \mathrm{CH}_{2}$ - and $\mathrm{Ph}$ for phenyl $\mathrm{C}_{6} \mathrm{H}_{5}$-groups (cf. also Goodman, $\mathrm{M}$. and Kenner, G. W. Advances in Protein Chem. 12 (1957) 509-518).

** Mellander, O. and Strid, L. of this laboratory; Personal communication.

Acta Chem. Scand. 13 (1959) No. 7 
general route to $\mathrm{O}$-phosphorylated serine peptides, applicable also to threonine peptides ${ }^{22}$ has been reported. The synthesis of the L, D and DI forms of O-phosphorylserine ${ }^{19}$ as well as of di and tri-peptides of this amino acid and glycine 18,20 were described. In the route followed, the peptide sequence in question is first synthesized by resorting to coupling methods which allow the use of unprotected serine hydroxyl groups. Protecting groups for the amino and carboxyl functions ( $\mathrm{N}$-carbobenzoxy groups ${ }^{23}$; benzyl esterification ${ }^{24}$ ) are selected, which are stable under the conditions of phosphorylation but which afterwards are eliminated by mild treatment (catalytic hydrogenolysis). The compounds so obtained, $i$. e. the $\mathrm{N}$-carbobenzoxypeptide benzyl esters, are then phosphorylated with dibenzylphosphoryl ${ }^{25}$ or diphenylphosphoryl ${ }^{26,27}$ chloride, and the resulting triesters of phosphoric acid finally catalytically hydrogenolysed into free phosphopeptides, and into the volatile degradation products of the protecting groups, benzene (or cyclohexane in platinum catalysed hydrogenation), toluene (methylcyclohexane) and carbon dioxide:

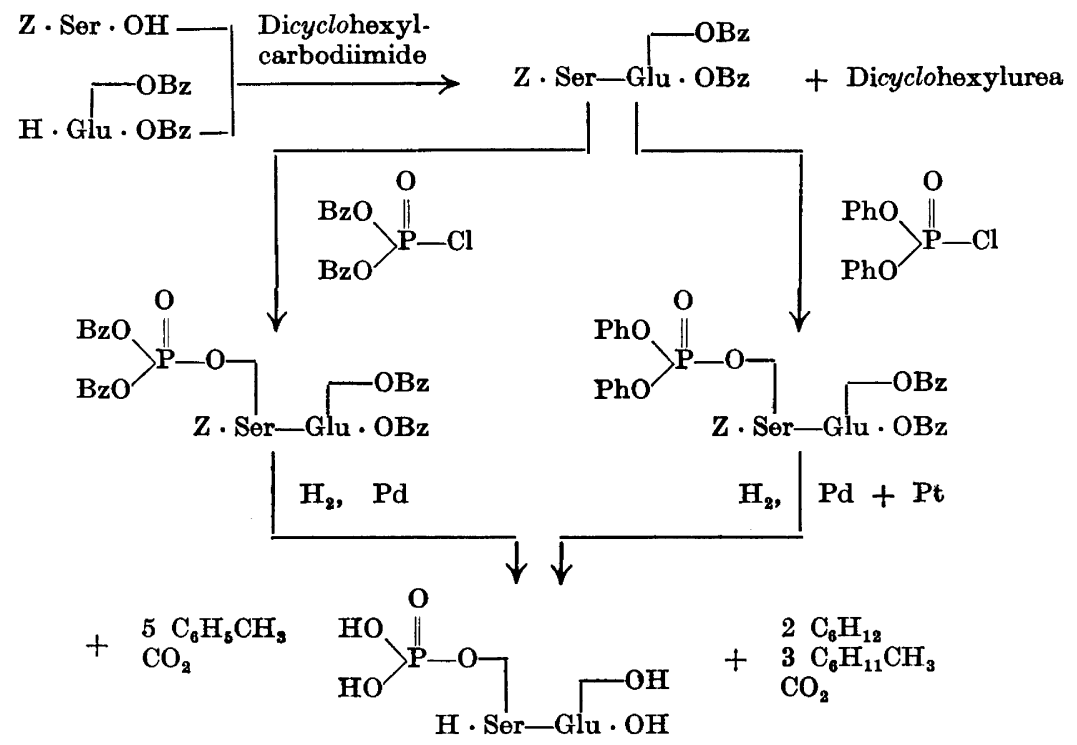

Such procedures are avoided as much as possible, that are suspected of causing racemization, hydrolysis of phosphate ester or peptide bonds, and acyl migrations ${ }^{28-29}$ or $\beta$-elimination ${ }^{22}$, e.g. treatment with strong acids or alkalies. The present paper describes the use of this procedure in the synthesis of six dipeptides of $\mathrm{O}$-phosphorylated L-serine, combined with I-glutamic acid, $\mathrm{L}$-aspartic acid and $\mathrm{L}$-leucine.

\section{DIPEPTIDE DERIVATIVES OF L-SERINE}

The $\mathrm{N}$-carbobenzoxy dipeptide benzyl esters required for the phosphorylation were prepared from $\mathrm{N}$-carbobenzoxyamino acids ${ }^{23}$ and amino acid benzyl 
esters by the application of the carbodiimide procedure ${ }^{30-31}$, which, besides its simplicity, allows the use of unprotected serine hydroxyl groups. The yields obtained by this procedure are frequently excellent, providing acylurea formation ${ }^{30-32}$ can be avoided. For this purpose a mixture of tetrahydrofuran and acetonitril as recommended by Zahn and Diehl ${ }^{32}$, was used as solvent in couplings with $\mathrm{N}$-carbobenzoxy-L-serine, and in no case could a formation of $\mathrm{N}\left(\mathrm{N}\right.$-carbobenzoxyseryl)-N,N'-dicyclohexylurea ${ }^{32}$ be observed. Couplings with more soluble carbobenzoxy derivatives were made in a methylene chloride solution. Although serine is considered to be one of the most easily racemizing $\alpha$-amino acids ${ }^{33}$, no signs of racemization were observed in the coupling reactions, a fact which supports the general view that $\mathrm{N}$-acylamino acids, in contrast to $\mathrm{N}$-acyl peptides, produce fully optically pure compounds when coupled by the carbodiimide or mixed anhydride procedure *. It should, however, be kept in mind, that minor quantities of diastereoisomers possibly formed may be eliminated in the isolation and purification of the reaction product, as the solubility of diastereoisomeric peptide derivatives is often sufficiently different to allow their separation (cf. the following paper ${ }^{21}$ ). The optical purity of two of the protected peptide derivatives was clearly demonstrated by hydrogenol-

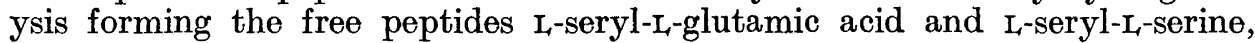
which had already been prepared by the azide procedure ${ }^{38-39}$. The additional four dipeptides of $\mathrm{L}$-serine, obtained in the present work, had not been previously reported. The peptides and their protected derivatives are listed in Tables 2 and 3.

\section{PHOSPHORYLATION OF PROTECTED L-SERINE PEPTIDES AND HYDRO- GENOLYSIS OF THE TRIESTERS OBTAINED}

Among the various methods of phosphorylation reported in the literature, only those could be considered at the present time, in which a monofunctional phosphoryl chloride ${ }^{25-27,}$ 40-42 or a suitably protected pyrophosphate ${ }^{43-45}$ was used for the phosphorylation of the free hydroxyl groups. Diphenylphosphoryl and dibenzylphosphoryl chlorides were used exclusively for the experiments, owing to their availability and simplicity in operation.

A. Peptidederivatives of diphenylphosphoric acid

Diphenylphosphoryl chloride reacts readily with primary (serine) and secondary (threonine) alcohols, yielding $90 \%$ or more of O-diphenylphosphoryl

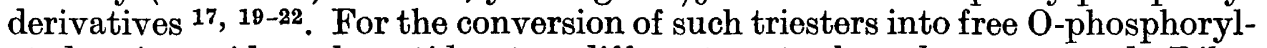
ated amino acids and peptides, two different routes have been reported. Riley et $a l .{ }^{22}$ have used alkaline dephenylation with simultaneous saponification of carboxylic ester groups, the $\mathrm{N}$-carbobenzoxy group having first been removed

\footnotetext{
* Partial racemization has been observed when $\mathrm{N}$-acylated peptides have been coupled by these methods ${ }^{34-36}$. On the other hand, two tetrapeptide derivatives were recently condensed by carbodiimide, yielding an apparently optically pure octapeptide derivative ${ }^{37}$.
} 
with hydrogen bromide in glacial acetic acid. Keeping the well established sensitivity of serine peptide derivatives to alkali in mind * the low yields of the two phosphopeptides obtained by this process, H.SerP-Gly.OH and $\mathrm{H} \cdot \mathrm{SerP}-\mathrm{Glu} \cdot \mathrm{OH}$ and the low melting point of the former and optical rotation of the latter as compared with the compounds prepared by hydrogenolysis may be explained. Furthermore, this route can be used for $N$-terminal $\mathrm{O}$ phosphorylserine peptides only, as a free $\alpha$-amino group at the phosphorylated serine residue is necessary to avoid the $\beta$-elimination reaction in alkaline solution ${ }^{22}$.

A second method for the removal of the phenyl, benzyl and $\mathrm{N}$-carbobenzoxy groups consists in applying catalytic hydrogenolysis. Although exceptionally mild conditions can be used in such a case, this route shows a disadvantage in the difficulty by which complete hydrogenolytic removal of the phenyl groups is obtained 17, 19-21.

The hydrogenolysis of diphenylphosphorylated derivatives of amino acids and peptides is usually performed in two stages, first using a palladium catalyst and then a platinum catalyst ${ }^{19,49}$. It has been stated ${ }^{50}$, that only benzyl groups are eliminated by palladium-catalyzed hydrogenolysis:
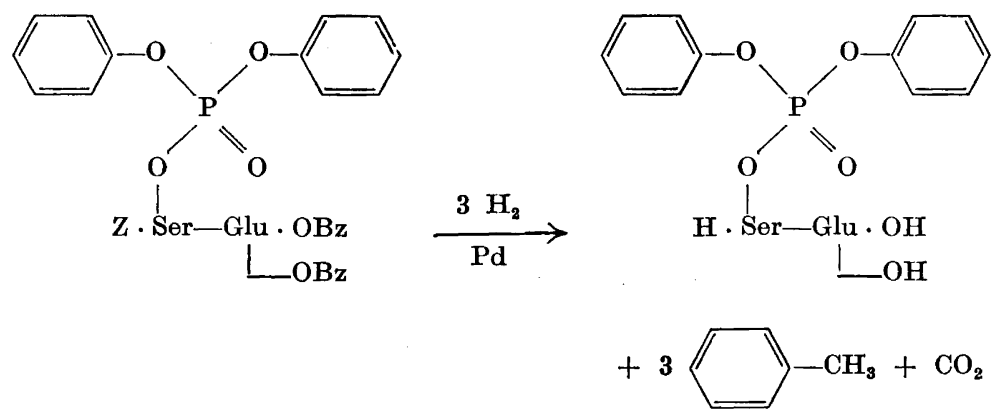

Mostert et al. ${ }^{50}$ suggest that the claimed inertness of phenylic esters to $\mathrm{H}_{2} / \mathrm{Pd} / \mathrm{C}$ depends on the fact that the phenyl ring has to be converted to cyclohexyl derivative prior to elimination, and that only platinum ** catalyzes this ring hydrogenation. (see p. 1411).

Our work does not confirm the absolute selectivity of the palladium (on charcoal) catalyst, but the cleavage of phenyl groups seems to be very slow, as indicated, for example, in the following experiment. Palladium catalyzed hydrogenolysis of O-diphenylphosphoryl-N-carbobenzoxy-DI-serine benzyl ester $^{19}$ in ethanol-water solution was followed by measuring the hydrogen

* Saponification of $\mathrm{N}$-carbobenzoxypeptide esters containing serine frequently produces low yields of carbobenzoxypeptide owing to side reactions ${ }^{46-47}$. Selective racemization of the serine residue in $\mathrm{N}$-carbobenzoxy-L-serylglycyl-L-alanine ethyl ester has been produced by treatment with triethylamine ${ }^{48}$.

** The palladium catalyst of Kuhn and Haas, which catalyzes hydrogenolytic cleavage of $\mathrm{N}$-aryl groups has been shown to catalyze ring hydrogenation of several aromatic compounds ${ }^{51}$. 

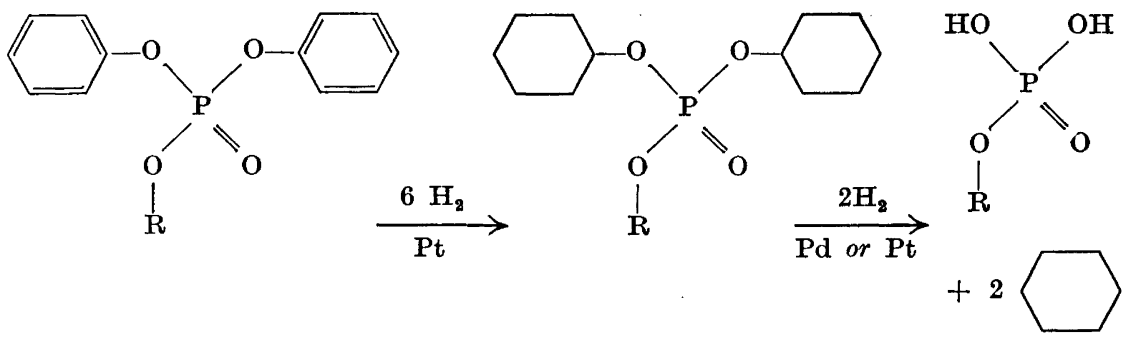

uptake and by paper chromatographic analysis, the results of which are shown in Table 1.

Table 1.

\begin{tabular}{|c|c|c|c|c|}
\hline \multirow{2}{*}{$\begin{array}{c}\text { Reaction } \\
\text { time in min }\end{array}$} & $\begin{array}{c}\text { Hydrogen } \\
\text { consumption } \\
\text { ml (moles) }\end{array}$ & $\begin{array}{c}\text { Derivatives of serine identified by paper } \\
\text { chromatography }\end{array}$ \\
\cline { 3 - 5 } & $\begin{array}{c}\text { Diphenyl- } \\
\text { phosphoryl }\end{array}$ & $\begin{array}{c}\text { Monophenyl- } \\
\text { phosphoryl }\end{array}$ & O-phosphoryl \\
\hline 10 & $\begin{array}{l}200(1.8) \\
235(2.05)\end{array}$ & $\begin{array}{c}++++ \\
++++\end{array}$ & $\begin{array}{c}\text { Traces } \\
+++\end{array}$ & 0 \\
60 & $\begin{array}{l}245(2.1) \\
250(2.2)\end{array}$ & +++ & 0 \\
180 & & & Traces \\
\hline
\end{tabular}

From the final product $56 \%$ of recrystallized O-diphenylphosphoryl-DLserine was isolated. The appearance of monophenyl derivative after prolonged reaction time is very probably a result of hydrogenolytic cleavage and not of hydrolysis *, since diphenylphosphorylserine is comparatively stable in neutral solution. In alkaline solution **, however, phosphate is readily released (Fig. 1).

Results obtained by palladium catalyzed hydrogenolysis of peptide derivatives are very similar although hydrolysis forming unphosphorylated peptide and free amino acids thereby seems to occur to a somewhat greater extent as evidenced by paper chromatography.

Platinum catalysts have been successfully used for hydrogenolytic cleavage of numerous $\mathrm{O}$-diphenylphosphorylated sugar derivatives. Complete removal of the phenyl groups of O-diphenylphosphorylated peptide derivatives, however, is very difficult ***. Appreciable amounts of $\mathrm{O}$-monophenylphosph-

* Bevan et al. ${ }^{52}$ obtained $O$-monophenylphosphoryl derivatives in similar experiments either with a palladium or platinum catalyst.

** Zervas and Katsoyannis ${ }^{53}$ converted $\mathrm{N}$-diphenylphosphorylated amino acid derivatives to $\mathrm{N}$-monophenylphosphorylated compounds by treatment with barium hydroxide. Similar results have been obtained by Moffatt and Khorana ${ }^{45}$.

*** Moffatt and Khorana ${ }^{45}$ observed a similar difficulty in the hydrogenolysis of di- $p$-nitrophenylphosphorylated derivatives, the addition of a strong acid, such as hydrochloric acid, being necessary to eliminate the aryl group from the mono-p-amino-phenyl-phosphoryl derivatives initially formed.

Acta Chem. Scand. 13 (1959) No. 7 


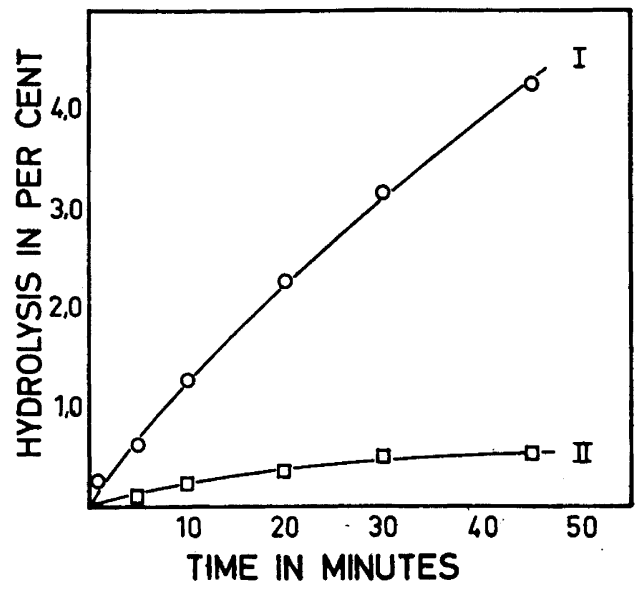

Fig. 1. Release of phosphoric acid from $0.01 \mathrm{M}$ solutions of O-diphenylphosphorylDL-serine (I) and O-monophenylphosphorylDL-serine (II) at pH 9.5 (0.1 M ethanolamine - hydrochloric acid buffer) and $25^{\circ}$. Phosphorus determined according to Beerenblum and Chain, Biochem. J. 32 (1958) 295.

orylated peptide remain unaffected after hydrogenolysis with palladium on charcoal as catalyst, removal of this catalyst together with possibly occurring catalyst poisons and the repeated hydrogenolysis with platinum oxide as catalyst, regardless if acetic acid, ethanol-water or ethanol-water-hydrochloric acid is used as the solvent. This incomplete hydrogenolysis cannot be the result of insolubility ${ }^{52}$, since several monophenylphosphorylated derivatives, e.g. those of serylglutamic and serylaspartic acid, are easily dissolved by the solvents used. Furthermore, isolated and purified monophenylphosphorylated derivatives are rapidly and completely hydrogenolysed to form free phosphopeptides in either of these solvents.

\section{B. Derivatives of dibenzylphosphoric acid}

In contrast to the diphenylphosphates, dibenzylphosphorylated derivatives 54 of peptides are rapidly and completely hydrogenolysed to form free phosphopeptides in a single stage, using a palladium catalyst. Although it has been stated to the contrary ${ }^{55}$, dibenzylphosphoryl chloride does react with serine hydroxyl groups ${ }^{18}$. By careful working at low temperature the triester yield will be as high as $75 \%$. Some of the triesters have been obtained in a crystalline state (Table 5). They can rapidly be hydrogenolysed with the use of palladium on charcoal as catalyst, $1 / 2-2 \mathrm{~h}$ being sufficient. As a consequence of the rapid hydrogenolysis, very slight hydrolysis, if any, takes place. The yield of purified phosphopeptide is about $80 \%$, which corresponds to an overall yield of about $40 \%$, calculated from L-serine.

\section{PURIFICATION AND PROPERTIES OF O-PHOSPHORYLATED PEPTIDES}

The only by-products observed when preparing phosphopeptides via hydrogenolysis of dibenzylphosphorylated derivatives have been traces of unphosphorylated peptides and amino acids. By recrystallization, or by 


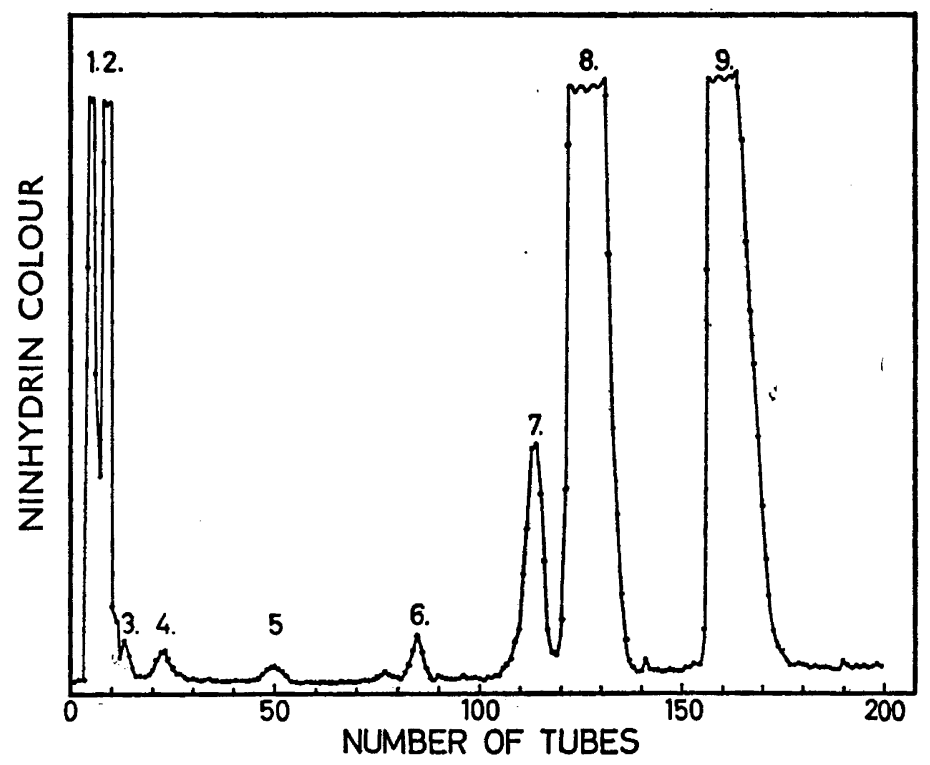

Fig. 2. Anion exchange chromatographic separation of the products obtained by platinum catalyzed hydrogenolysis of $\mathrm{O}$-diphenylphosphoryl-N-carbobenzoxy-I,-seryl-L,-glutamic acid dibenzyl ester, as indicated by quantitative ninhydrin reaction. The two main products are: (8)O-phosphoryl-L-seryl-L-glutamic acid and (9) its monophenyl derivative. Fractions (5) and (6) are probably glutamic acid and O-phosphorylserine. Fraction 7 has not been identified.

treatment in water solution with a cation exchange resin (Amberlite IR 120 or Dowex $50, \mathrm{H}^{+}$-form), followed by evaporation and recrystallization (or precipitation), the phosphopeptides are easily obtained in a chromatographically and analytically pure state.

The reaction products obtained after hydrogenolysis of O-diphenylphosphorylated derivatives contain variable amounts of amino acids, unphosphorylated and monophenylphosphorylated peptides in addition to the desired phosphopeptides (Fig. 2). The latter have in several cases been successfully purified by fractional crystallization, with or without additional use of cation exchange resin ${ }^{17}$, 19-20. Several O-phosphorylated peptides, especially those of the more acidic type, containing glutamic and aspartic acid, however, are hygroscopic compounds and therefore difficult to crystallize. Separation of the reaction products is then most successfully accomplished by chromatographic procedures. Partition chromatography on cellulose has been applied to the reaction products obtained by hydrogenolysis of $\mathrm{O}$-diphenylphosphoryl$\mathrm{N}$-carbobenzoxy-DL-serylglycine benzyl ester, using $n$-butanol-acetic acidwater as an eluent $*$. Another process ${ }^{57}$, using anion exchange resin, has also been successfully used in several cases in this laboratory, (cf. Fig. 2).

* The author, unpublished experiments. Jones and Lipkin ${ }^{56}$ have used acetone-acetic acidwater for similar purposes.

Acta Chem. Scand. 13 (1959) No. 7 
Purification of phosphorylated peptides may also be achieved, with the use of barium, lead and brucine salts $6,7,22$.

Among the peptides reported in this paper, the O-phosphoryl-L-seryl-Lglutamic acid (compound 13, Table 4) may be of special interest, being the first phosphopeptide isolated from casein. The peptide isolated by Levene and Hill ${ }^{6}$ and by Schmidt ${ }^{7}$ was shown by Posternak and Pollaczek ${ }^{11}$ to have the serine in $\mathrm{N}$-terminal position, since this amino acid was absent in the hydrolysate of the peptide subsequent to deamination with nitrous acid. The analytical data of the barium and brucine salts, and the melting point of the latter, $171-172^{\circ}$, were reported. Riley et al. ${ }^{22}$ have obtained this phosphopeptide by the alkaline dephenylation process mentioned above. Their peptide,

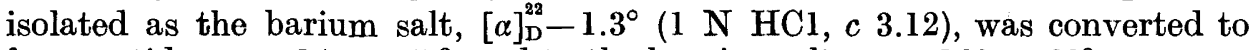
free peptide, m.p. $145-147^{\circ}$, and to the brucine salt, m.p. $160-162^{\circ}$.

Our compound (13) which does not posess a sharply defined melting point but sinters at about $145^{\circ}$ without decomposition has a much higher value of optical rotation, $[\alpha]_{\mathrm{D}}^{21}-9.5^{\circ} \pm 0.5^{\circ}(1 \mathrm{~N} \mathrm{HCl}, c 4.2, l 1)$. Although this higher value, by no means, is proof of higher optical purity in view of the fact that two asymmetric centers are present, a comparison with the rotation of unphosphorylated L-seryl-L-glutamic acid (compound 7, Table 3) indicates that the value of rotation appears to have the correct magnitude since substitution of the $\beta$-hydroxyl group in serine peptides with phosphoric acid has little influence on the molar rotation. Compound (13) was also converted to its brucine salt, which, after a single recrystallization from water-acetone, melted at $171-173^{\circ}$ with decomposition, thus confirming the results achieved by Levene and Hill. The action of intestinal alkaline phosphatase on O-phosphorylated peptides and their derivatives ${ }^{16}$, and the acid hydrolysis ${ }^{58}$ and acid ionization constants ${ }^{17}$ of some of the phosphopeptides have been reported elsewhere.

\section{EXPERIMENTAL}

Where not otherwise stated, the compounds were dried at room temperature in vacuo over phosphorus pentoxide. The melting points were determined by the use of capillary tubes and are uncorrected. In the matter of paper chromatography on Whatman No. 1 paper, the following solvent systems were used: (I) Phenol-water $(80 / 20 \mathrm{v} / \mathrm{v})$, ascending, $6 \mathrm{~h}$ and (II) $n$-butanol-acetic acid-water $(40 / 10 / 50 / \mathrm{v} / \mathrm{v}$ ), descending, $18 \mathrm{~h}$ (cf. Table 6).

\section{I - Serine benzyl ester}

The racemic form of serine benzyl ester has been prepared by various procedures ${ }^{22,32,55,59}$. The pure optical antipodes have been obtained as hydrochlorides after separation of the dibenzoyl-D-tartrates ${ }^{89}$. The $\mathrm{L}_{\mathrm{L}}$-form was prepared in this laboratory several years ago by the process evolved by Cipera and Nicholls ${ }^{60}$ :

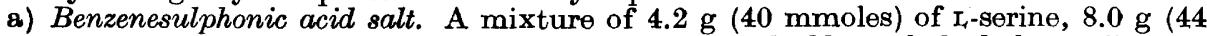
mmoles) of recrystallized benzenesulphonic acid and $20 \mathrm{ml}$ of benzyl alcohol was distilled with carbon tetrachloride on a water bath until no more water was formed $(3-5 \mathrm{~h})$. The ester salt was precipitated with dry ether and was, after some hours at $+4^{\circ}$, filtered off, washed with ether and dried. The yield amounted to about $13.5 \mathrm{~g}, \mathrm{~m} . \mathrm{p} .85-90^{\circ}$. After recrystallization from $i$-propanol-ether, $10.2 \mathrm{~g}(72 \%), \mathrm{m}$. p. $110-112^{\circ}$ was obtained. (Found: $\mathrm{N}$ 4.1. Calc. for $\mathrm{C}_{16} \mathrm{H}_{10} \mathrm{O}_{6} \mathrm{NS}$ (353.4): $\mathrm{N}$ 4.0.) The reaction product is frequently difficult to crystallize, since no doubt by-products caused by, for example, selfesterification (forming O-peptide derivatives,) and O-benzylation ${ }^{\mathbf{3 2}}$ are formed. 
b) p-Toluenesulphonic acid salt. With the use of the above process, but employing $p$-toluenesulphonic acid monohydrate instead, $11.0 \mathrm{~g}(75 \%)$ of recrystallized $\mathrm{I}_{\mathrm{f}}$-serine benzyl ester $p$-toluenesulphonate, m. p. $94-95^{\circ}$, was obtained. (Found: N 3.8. Calc. for $\mathrm{C}_{17} \mathrm{H}_{21} \mathrm{O}_{6} \mathrm{NS}$ (367.4): $\mathrm{N}$ 3.8.)

c) Hydrochloride, prepared from a) and b). To a cold solution of 10 mmoles of a) $(3.5 \mathrm{~g})$ or b) $(3.7 \mathrm{~g})$ in $20 \mathrm{ml}$ of chloroform and $1.4 \mathrm{ml}(10 \mathrm{mmoles})$ of triethylamine, $100 \mathrm{ml}$ of dry ether was added. The cooled and filtered solution was then saturated at $0^{\circ}$ with hydrogen chloride. The precipitate was collected and recrystallized from $i$-propanolether, yielding $1.7 \mathrm{~g}(74 \%)$, m. p. 172-174,$[\alpha]_{\mathrm{D}}^{21}-4.1^{\circ} \pm 0.5^{\circ}$ (Methanol, $c 4.4, l 1$ ); reported ${ }^{59}[\alpha]_{\mathrm{D}}^{20}-4.19^{\circ}$ (Methanol, c 4.53). (Found: $\mathrm{N}$ 6.1. Calc. for $\mathrm{C}_{10} \mathrm{H}_{14} \mathrm{O}_{3} \mathrm{~N} \mathrm{Cl}$ (231.7): $\mathrm{N}$ 6.1.)

\section{N-Carbobenzoxy dipeptide benzyl esters}

Procedure a) To a solution of $20 \mathrm{mmoles}$ of an amino acid benzyl ester salt (L-serine benzyl ester benzenesulphonate, $7.1 \mathrm{~g}$; I-leucine benzyl ester $p$-toluenesulphonate ${ }^{61}$, $8.7 \mathrm{~g}$; L-aspartic acid dibenzyl ester $p$-toluenesulphonate ${ }^{61}, 8.7 \mathrm{~g}$; L-glutamic acid dibenzyl ester $p$-toluenesulphonate $\left.{ }^{61}, 9.0 \mathrm{~g}\right), 2.8 \mathrm{ml}(20 \mathrm{mmoles})$ of triethylamine and $4.8 \mathrm{~g}$ (20 mmoles) of $\mathrm{N}$-carbobenzoxy-L-serine ${ }^{47}$ in $80-100 \mathrm{ml}$ of tetrahydrofuran-acetonitril (1:1), was added $4.2 \mathrm{~g}$ (20 mmoles) of dicyclohexylcarbodiimide. On the following day the precipitate of urea derivative was removed by filtration and the solution poured into $2 \mathrm{l}$ of ice-cold water under vigorous stirring. After $4-12 \mathrm{~h}$ at $+4^{\circ}$ the precipitated peptide was collected, dried and recrystallized from ethyl acetate-light petroleum. The compounds obtained are listed in Table 2.

Table 2. N-Carbobenzoxy dipeptide benzyl esters. All compounds are of $\mathbf{L}-\mathbf{L}$ configuration.

\begin{tabular}{|c|c|c|c|c|c|c|}
\hline & Compound & $\begin{array}{c}\text { Yield } \\
\%\end{array}$ & $\underset{{ }^{\circ} \mathrm{C}}{\text { M. p. }}$ & Molecular formula & $\begin{array}{l}\text { Analysis, } \\
\text { Found }\end{array}$ & $\begin{array}{l}\% \mathrm{~N} \\
\text { Calc. }\end{array}$ \\
\hline 1 & $\mathrm{Z} \cdot$ Ser-Glu $\cdot \mathrm{OBz}$ & 78 & 125 & $\mathrm{C}_{30} \mathrm{H}_{32} \mathrm{O}_{8} \mathrm{~N}_{2}, 548.6$ & 5.2 & 5.1 \\
\hline & $\mathrm{Z} \cdot$ Ser-Asp $\cdot \mathrm{OBz}$ & 89 & $128-129$ & $\mathrm{O}_{8} \mathrm{~N}_{2}, 534.5$ & 5.2 & 5.2 \\
\hline & $\mathrm{Z} \cdot$ Ser-Leu $\cdot \mathrm{OBz}$ & 90 & $83-84$ & $\mathrm{C}_{24} \mathrm{H}_{30} \mathrm{O}_{6} \mathrm{~N}_{2}, 442.5$ & 6.3 & 6.3 \\
\hline & $\mathrm{Z} \cdot$ Ser-Ser $\cdot \mathrm{OBz}$ & 71 & $138-139$ & $\mathrm{C}_{21} \mathrm{H}_{24} \mathrm{O}_{7} \mathrm{~N}_{2}, 416.2$ & 6.5 & 6.7 \\
\hline & $\mathrm{Z} \cdot \mathrm{Glu}-\mathrm{Ser} \cdot \mathrm{OBz}$ & 76 & 127 & $\mathrm{C}_{30} \mathrm{H}_{32} \mathrm{O}_{8} \mathrm{~N}_{2}, 548.6$ & 5.2 & 5.1 \\
\hline 6 & $\mathbf{Z} \cdot$ Leu-Ser $\cdot \mathrm{OBz}$ & 86 & $122-123$ & $\mathrm{C}_{24} \mathrm{H}_{30} \mathrm{O}_{6} \mathrm{~N}_{2}, 442.5$ & 6.1 & 6.3 \\
\hline
\end{tabular}

Procedure b) To a solution of $7.1 \mathrm{~g}$ ( $20 \mathrm{mmoles}$ ) of $\mathrm{L}$-serine benzyl ester benzenesulphonate and $2.8 \mathrm{ml}(20 \mathrm{mmoles})$ of triethylamine in $100 \mathrm{ml}$ of methylene chloride was added, first, 20 mmoles of a carbobenzoxy derivative ( $\mathrm{N}$-carbobenxoxy-r-leucine, $5.3 \mathrm{~g} ; \mathrm{N}$-carbobenzoxy-L-glutamic acid $\gamma$-benzyl ester $\left.{ }^{62}, 7.4 \mathrm{~g}\right)$ and then $4.2 \mathrm{~g}(20 \mathrm{mmoles})$ of dicyclohexylcarbodiimide. On the next day the solution was filtered, washed with hydrochloric acid, water, sodium bicarbonate and water, and finally, after drying over sodium sulphate, evaporated to dryness in vacuo. The residue was then recrystallized from ethyl acetatelight petroleum (Table 2).

\section{Peptides of L-s erine}

Catalytic hydrogenolysis of the protected peptides (compounds $1-6 ; 2-5$ mmoles) in ethanol-water solution, using a $10 \%$ palladium on charcoal catalyst, after filtration, evaporation to dryness and recrystallization from water-ethanol, resulted in the free peptides (compounds $7-12$ ) listed in Table 3 .

\section{Phosphorylation with diphenylphosphorylehloride}

To a solution of 10 mmoles of an N-carbobenzoxypeptide benzyl ester (compounds $1-3,5-6)$ in $10 \mathrm{ml}$ of anhydrous pyridine was added $3.2 \mathrm{~g}$ (12 mmoles) of diphenylphosphoryl chloride, the temperature being kept below $40^{\circ}$. In the case of compound

Acta Chem. Scand. 13 (1959) No. 7 
Table 3. Dipeptides of $\mathrm{L}_{\mathrm{s}}$-serine

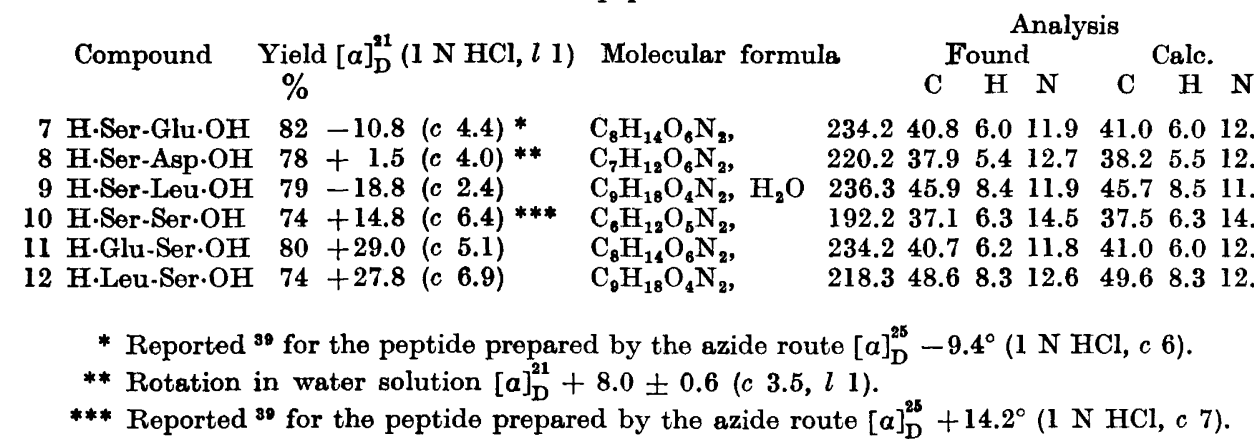

4, only 5 mmoles $(2.1 \mathrm{~g})$ were used, the two equivalents of chloride reacting readily with strong heat evolution. After $4 \mathrm{~h}$ at room temperature, the excess of acid chloride was destroyed by adding $1 \mathrm{ml}$ of water, and half an hour later the reaction mixture was taken up in $100 \mathrm{ml}$ of water and $100 \mathrm{ml}$ of ethyl acetate. The ethyl acetate layer was washed with cold $5 \mathrm{~N}$ sulphuric acid, water, bicarbonate solution and water, then dried over sodium sulphate and evaporated to dryness in vacuo. The triesters remained normally as colourless or slightly yellowish oils, of which those obtained from compounds 2 and 5 crystallized spontaneously (c.f. Table 5). The yield varied between 90 and $95 \%$.

\section{Phosphorylation with dibenzylphosphoryl chloride}

A solution of 10 mmoles of an $\mathrm{N}$-carbobenzoxypeptide benzyl ester (compounds 1,3 and corresponding derivatives of $L D$-serylglycine and glycyl-DL-serine) in $10 \mathrm{ml}$ of anhydrous pyridine was cooled to just above the freezing point in an ethanol-carbon dioxide bath, and dibenzylphosphoryl chloride, prepared from $3.7 \mathrm{~g}$ (14 mmoles) of dibenzyl phosphite ${ }^{25}$, was added. The mixture was shaken at this temperature for $15 \mathrm{~min}$ and then left over nigh at $0^{\circ}$. On the following day the almost colourless solution was worked up as above, yielding $\mathbf{7 5} \%$ of triesters as colourless oils (if the oils are considered to be $100 \%$ pure; they may contain some unphosphorylated neutral material). Two of them crystallized readily (Table 5).

In early experiments, phosphorylations were made at $0^{\circ}$. The yield of triester was then appreciably lower (about $50 \%$ ) and the product always more or less coloured.

Hydrogenolysis of O-diphenylphosphorylated derivatives of amino acidsand peptides

$-\mathrm{OPO}(\mathrm{OPh})_{2}$
a) Palladium catalyzed hydrogenolysis of $Z \cdot S e r \cdot O B z$. To a solution of $2.8 \mathrm{~g}$ (5 mmoles) of O-diphenylphosphoryl-N-carbobenzoxy-DL-serine benzyl ester ${ }^{19}$ in $75 \mathrm{ml}$ of ethanol, water was added to slight turbidity, and hydrogenolysis started with $0.5 \mathrm{~g} 10 \%$ palladium on charcoal. The shaking was stopped at intervals for the purpose of taking samples for paper chromatography, and then restarted. The results are shown in Table 1. After $3 \mathrm{~h}$, the catalyst was filtered off and washed with hot acetic acid-water $(1: 1)$, the solution evaporated to dryness and the residue recrystallized from acetic acidwater, yielding, in the cold, $0.95 \mathrm{~g}(56 \%)$ of O-diphenylphosphoryl-DL-serine, m.p. $130-131^{\circ}$ (decomp.), reported ${ }^{10} 129-130^{\circ}$.

b) Palladium catalyzed hydrogenolysis of $O$-diphenylphosphorylated peptide derivatives. In the hydrogenolytic conversion of the triesters obtained from diphenylphosphoryl 


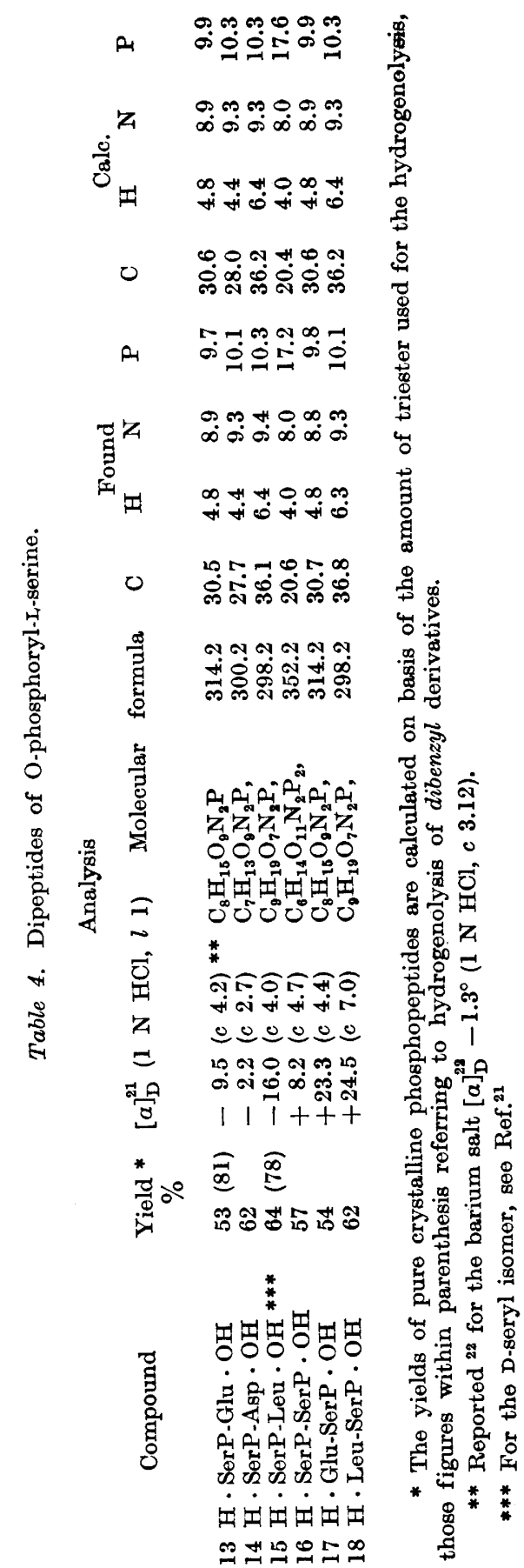

Acta Chem. Scand. 13 (1959) No. 7 
Table 5. Dibenzyl, diphenyl and monophenyl phosphorylated derivatives.

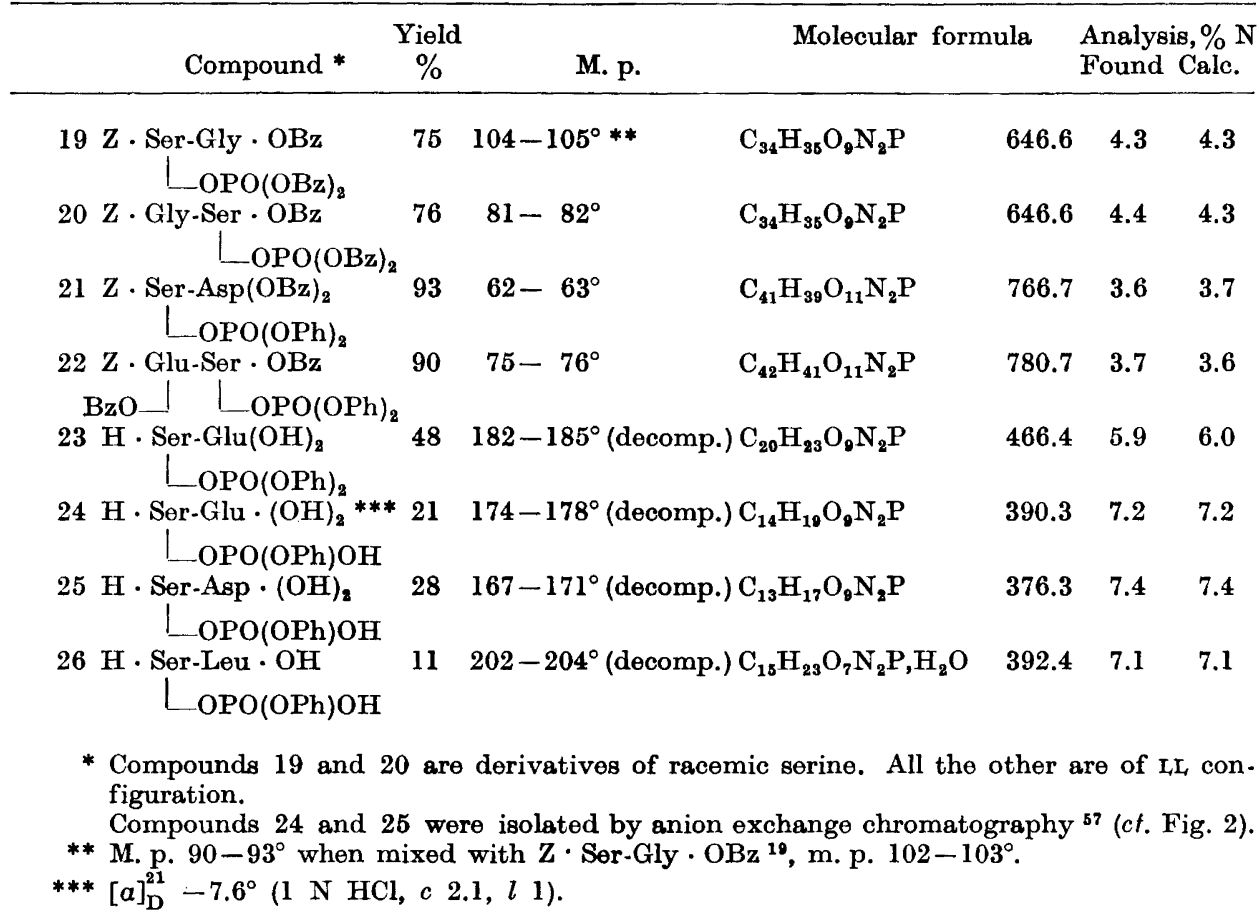

chloride and compounds $(1-6)$ to free phosphorylated peptides, palladium on charcoal was used in the first stage as per above. When the hydrogen uptake ceased, the catalyst was filtered off, and the solution and washings were evaporated to dryness. (The residue was then hydrogenolysed with a platinum catalyst as described below (c)). Paper chromatographic analysis of the residue showed at this stage the presence of large amounts of O-diphenylphosphorylated peptides, one of which was isolated and purified by recrystallization (comp. 23). Appreciable quantitites of other ninhydrinpositive compounds were also present.

c) Platinum catalyzed hydrogenolysis. The palladium-hydrogen treated product above (b) was dissolved in glacial acetic acid and rehydrogenolysed, now with Adams platinum oxide as catalyst. After an initial rapid hydrogen consumption lasting from $1 / 2$ to $2 \mathrm{~h}$, the reaction slowed down, and after $4-8 \mathrm{~h}$ no further hydrogen was consumed. The addition of a new catalyst or water had no marked effect. The filtered solution was evaporated to dryness and the residue analyzed by paper chromatography. In addition to the desired O-phosphorylated peptide, and its monophenylphosphoryl derivative, hydrolysis products were present. Re-hydrogenation with new catalyst in either acetic acid, ethanol-water or ethanol-water-hydrochloric acid did not increase the yield of phosphopeptide. Pure phosphopeptides (compounds 13-18, Table 4) were obtained by treatment in water solution with cation exchange resin (Dowex 50, $\mathrm{H}+$-form), evaporation to dryness and repeated recrystallization or precipitation from water with ethanolether, Compounds 13,14,16, 24 and 25, being difficult to obtain chromatographically pure by this method, were also obtained by separation of the products of hydrogenolysis by anion exchange column chromatography on a $2 \times 30 \mathrm{~cm}$ column of Dowex $1, \mathrm{X} 2$ resin in formate form, using gradient elution with pyridinium formate ${ }^{57}$. The fractions emerging from the column were tested by quantitative ninhydrin reaction and the peaks 
Table 6. $R_{\text {ser }}$ values of peptides, O-phosphorylated peptides, and other ninhydrin-positive derivatives of $\mathrm{L}$-serine.

\begin{tabular}{|c|c|c|c|c|c|c|c|c|}
\hline \multicolumn{3}{|c|}{ Dipeptides } & \multicolumn{3}{|c|}{ Phosphopeptides } & \multicolumn{3}{|c|}{ Derivatives } \\
\hline \multirow{2}{*}{$\begin{array}{c}\text { Compound } \\
\text { No. }\end{array}$} & \multicolumn{2}{|c|}{$R_{\text {ser }} *$} & \multirow{2}{*}{$\begin{array}{c}\text { Compound } \\
\text { No. }\end{array}$} & \multicolumn{2}{|c|}{$\boldsymbol{R}_{\mathrm{ser}}$} & \multirow{2}{*}{$\begin{array}{c}\text { Compound } \\
\text { No. }\end{array}$} & \multicolumn{2}{|c|}{$\mathbf{R}_{\text {ser }}$} \\
\hline & I & II & & I & II & & I & II \\
\hline 7 & 0.6 & 1.2 & 13 & 0.3 & 0.4 & 23 & & 3.5 \\
\hline 8 & 0.5 & 1.1 & 14 & 0.2 & 0.3 & 24 & 1.4 & 1.6 \\
\hline 9 & 2.2 & 3.3 & 15 & 0.8 & 1.8 & 25 & 1.3 & 1.4 \\
\hline 10 & 0.6 & 1.0 & 16 & 0.1 & 0.1 & 26 & 1.6 & 3.3 \\
\hline 11 & 0.6 & 1.2 & 17 & 0.2 & 0.3 & & & \\
\hline 12 & 2.0 & 3.0 & 18 & 0.7 & 1.4 & & & \\
\hline
\end{tabular}

$* R_{\text {ser }}=\frac{R_{F} \text { for the compound }}{R_{F} \text { for serine }}$. Solvent systems used for the paper chromatography are (I) phenol-water $(80 / 20 \mathrm{v} / \mathrm{v})$ and (II) $n$-butanol-acetic acid-water $(40 / 10 / 50 \mathrm{v} / \mathrm{v}) . R_{F}$ for serine is (I) 0.35 ; (II) 0.18 .

thus obtained (Fig. 2) analyzed by paper chromatography. Those fractions containing phosphopeptide or monophenylphosphorylated peptide were evaporated to dryness in vacuo. The residues, probably being monopyridinium salts as indicated by elementary analysis, were dissolved in a small volume of water and converted to free acid by passage through a small column of Dowex $50(\mathrm{H}+)$ resin and then lyophilized (Tables 4 and 5$)$.

d) Rehydrogenation of O-monophenylphosphorylated derivatives. The solution of 1 mmole of compounds $(24-26)$ in $15 \mathrm{ml}$ of glacial acetic acid, water or ethanol-water was shaken with $0.1 \mathrm{~g}$ of platinum oxide in an atmosphere of pure hydrogen. Complete removal of the phenyl group was effected in $1 / 2-2 \mathrm{~h}$, as shown by paper chromatography and by isolation of pure phosphopeptide in about $85 \%$ yield by evaporation to dryness of the filtered solution.

When left for shaking in solvents containing water, appreciable hydrolysis into unphosphorylated peptide and into amino acids occurred, as found by paper chromatography.

\section{Preparation of O-phosphorylated peptides from O- dibenzylphosphorylated derivatives}

A solution of 5-10 mmoles of an (oily or solid) O-dibenzylphosphoryl-N-carbobenzoxy dipeptide benzyl ester in $75-100 \mathrm{ml}$ of ethanol, water being added to slight turbidity, was shaken together with $0.5-1 \mathrm{~g}$ of $10 \%$ palladium on charcoal in an atmosphere of pure hydrogen. In the first hour, at least $85 \%$ of the theoretical amount of hydrogen $\left(4-5\right.$ equiv. $\left.\mathrm{H}_{2}\right)$ was absorbed, and the reaction was normally completed within a further hour, no more hydrogen being used. The catalyst was filtered off and washed with a small amount of hot distilled water, and the filtrate and washings evaporated to dryness. The crystalline residue was washed with acetone or ethanol-ether, and dried. Paper chromatography of the product showed the presence of traces of unphosphorylated peptide and (or) free amino acids. In the case of well crystallizing compounds such as

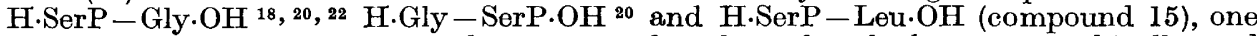
or two recrystallizations from hot water-ethanol produced chromatographically and analytically pure phosphopeptides. Since H.SerP-Glu.OH (compound 13) did not crystallize well from solvents containing water * it was purified as follows. The solution

* No other solvents have been found sufficiently effective; although boiling methanol dissolves appreciable amounts of phosphopeptides, we cannot at the present time exclude the possibility of partial esterification of these strongly acidic compounds.

Acta Chem. Scand. 13 (1959) No. 7 
of $1.0 \mathrm{~g}$ in $40 \mathrm{ml}$ of water was shaken with $2 \mathrm{ml}$ of Dowex 50 cation exchange resin $(\mathrm{H}+$-form) for $10 \mathrm{~min}$. The mixture was then filtered through a column, the resin washed with $5 \mathrm{ml}$ of water and the solution evaporated to dryness, yielding $0.9 \mathrm{~g}$. The compound was dissolved in $4 \mathrm{ml}$ of water and precipitated with $25 \mathrm{ml}$ of ethanol and $25 \mathrm{ml}$ of ether, the yield of collected and dried precipitate of pure phosphopeptide then being $0.85 \mathrm{~g}$ (Table 4).

\section{Brucine and barium salts of $\mathrm{H} \cdot \mathrm{SerP}-\mathrm{Glu} \cdot \mathrm{OH}$}

a) Brucine salt. The solution of $0.95 \mathrm{~g}$ ( 3 mmoles) of compound 13 (Table 4) in $25 \mathrm{ml}$ of water was treated with an excess of brucine $(5 \mathrm{~g})$ dissolved in $25 \mathrm{ml}$ of methanol. Further $75 \mathrm{ml}$ of water was added, and the excess of brucine extracted with $3 \times 30 \mathrm{ml}$ of chloroform. The water solution was filtered and evaporated to dryness, and the remaining crystalline product recrystallized by dissolving in $15 \mathrm{ml}$ of water and adding aceton at the boiling point. After $4 \mathrm{~h}$ at $+4^{\circ}$, the compound was collected and dried, the yield then being $2.3 \mathrm{~g}, \mathrm{~m} . \mathrm{p} .17 \mathrm{l}-173^{\circ}$ (decomp.), after a slight change in colour at $165^{\circ}$. (Found: $\mathrm{N}$ 7.9. Calculated, according to Levene and Hill ${ }^{6}$, for the monobrucine salt, $\mathrm{C}_{31} \mathrm{H}_{41} \mathrm{O}_{13} \mathrm{~N}_{4} \mathrm{P}$ 708.7): $\mathrm{N}$ 7.9.)

b) Barium salt. The above brucine salt $(2.0 \mathrm{~g})$ was dissolved in $25 \mathrm{ml}$ of water and neutralized (to phenolphthalein) with barium hydroxide solution. The precipitate of brucine was extracted with chloroform, the water solution concentrated in vacuo to $35 \mathrm{ml}$ and the barium salt of compound 13 precipitated with $100 \mathrm{ml}$ of ethanol. After centrifugation and reprecipitation from $50 \mathrm{ml}$ of water with $50 \mathrm{ml}$ of ethanol, the salt was collected by centrifugation and dried, yielding $0.9 \mathrm{~g}$. (Found: $\mathrm{N} \mathrm{5.4}$. Calculated for the tribarium salt $\left(\mathrm{C}_{8} \mathrm{H}_{9} \mathrm{O}_{10} \mathrm{NPBa}\right)_{2} \mathrm{Ba}$ (1034.4): $\mathrm{N}$ 5.4.)

Acknowledgements. The author wishes to express his sincere thanks to Professor Olof Mellander for his interest and support in this work.

The work was supported by grants from Swedish Medical Research Council to Professor Olof Mellander.

\section{REFERENCES}

1. Mc Meekin, T. L. and Polis, B. D. Advances in Protein Chem. 5 (1949) 201.

2. Mellander, O. and deVerdier, C.-H. Acta Soc.Med.Upsaliensis 57 (1952) 218.

3. Österberg, R. Arkiv Kemi 13 (1959) 409.

4. Pantlitschko, M. and Gründig, E. Monatsh. 89 (1958) 274; 489.

5. Bennich, H., Johansson, B. and Österberg, R. Acta Chem. Scand. 13 (1959) 1171.

6. Levene, P. A. and Hill, D. W. J. Biol. Chem. 101 (1933) 711.

7. Schmidt, G. Z.physiol. Chem. Hoppe-Seyler 223 (1934) 86.

8. de Verdier, C.-H. Acta Soc. Med. Upsaliensis 60 (1955) 48.

9. Hipp, N. J., Groves, M. L. and Mc Meekin, T. L. J. Am. Chem. Soc. 79 (1957) 2559.

10. Flavin, M. J. Biol. Chem. 210 (1954) 771.

11. Posternak, T. and Pollaczek, H. Helv. Chim. Acta 24 (1941) 921.

12. Mellander, O. Upsala Läkarefören. Förh. 52 (1947) 107.

13. Mellander, O. Acta Soc. Med. Upsaliensis 55 (1950) 247.

14. Posternak, T. and Grafl, S. Helv. Chim. Acta 28 (1945) 1258.

15. Bennich, H., Johansson, B. and Mellander, O. Acta Soc. Med. Upsaliensis 62 (1957) 67.

16. Mellander, O., Bennich, H. and Fölsch, G. Acta Soc. Med. Upsaliensis 64 (1959) 303.

17. Fölsch, G. and Österberg, R. J. Biol. Chem. 234 (1959) 2298

18. Fölsch, G. Acta Chem. Scand. 9 (1955) 1039.

19. Fölsch, G. and Mellander, O. Acta Chem. Scand. 11 (1957) 1232.

20. Fölsch, G. Acta Chem. Scand. 12 (1958) 561.

21. Fölsch, G. Acta Chem. Scand. 13 (1959) 1422.

22. Riley, G., Turnbull, T. H. and Wilson, W. J. Chem. Soc. 19571373.

23. Bergmann, M. and Zervas, L. Ber. 65 (1932) 1192.

24. Bergmann, M., Zervas, L. and Ross, W. F. J. Biol. Chem. 111 (1935) 245.

Acta Chem. Scand. 13 (1959) No. 7 
25. Atherton, F. A., Openshaw, H. T. and Todd, A. R. J. Chem. Soc. 1945382.

26. Zeile, K. and Meyer, H. Z. physiol. Chem. Hoppe-Seyler 256 (1938) 131.

27. Brigl, P. and Müller, H. Ber. 72 (1939) 2121.

28. Plapinger, R. E. and Wagner-Jauregg, T. J. Am. Chem. Soc. 75 (1953) 5755.

29. Josefsson, L. and Edman, P. Biochim. et Biophys. Acta 25 (1957) 614.

30. Sheehan, J. C., Goodman, M. and Hess, G. P. J. Am. Chem. Soc. 78 (1956) 1367.

31. Khorana, H. G. Chem. \& Ind. London 19551087.

32. Zahn, H. and Diehl, J. F. Z. Naturforsch. 12 b (1957) 85.

33. Daft, F. S. and Coghill, R. D. J. Biol. Chem. 99 (1931) 213.

34. Hofmann, K., Woolner, M. E., Spühler, G. and Schwartz, E. T. J. Am. Chem. Soc. 80 (1958) 1486.

35. Anderson, G. W. and Callahan, F. M. J. Am. Chem. Soc. 80 (1958) 2902.

36. Schwarz, H. and Bumpus, F. M. J. Am. Chem. Soc. 81 (1959) 890.

37. Boissonas, R. A., Guttmann, St., Huguenin, R. L., Jaquenoud, P.-A. and Sandrin, Ed. Helv. Chim. Acta 41 (1958) 1867.

38. Curtius, T. Ber. 35 (1902) 3226.

39. Fruton, J. S. J. Biol. Chem. 146 (1942) 463.

40. Baer, E. Biochem. Preparations 1 (1949) 51; 2 (1952) 96.

41. Zervas, L. and Dilaris, I. J. Am. Chem. Soc. 77 (1955) 5354.

42. Miyano, M. and Funahashi, S. J. Am. Chem. Soc. 77 (1955) 3522.

43. Atherton, F. A. and Todd, A. R. J. Chem. Soc. 1947674.

44. Zervas, L. and Dilaris, I. Chem. Ber. 89 (1956) 925.

45. Moffatt, J. G. and Khorana, H. G. J. Am. Chem. Soc. 79 (1957) 3741.

46. Harris, J. I. and Fruton, J. S. J. Biol. Chem. 191 (1951) 143.

47. Guttmann, St. and Boissonas, R. A. Helv. Chim. Acta 41 (1958) 1852.

48. Schnabel, E. Z. physiol. Chem. Hoppe-Seyler 314 (1959) 114.

49. Baer, E. and Stancer, H. C. Can. J. Chem. 34 (1956) 436.

50. Mostert, Pzn, S., Stegerhoek, L. J. and Verkade, P. E. Rec. trav. chim. 77 (1958) 133.

51. Kuhn, R. and Haas, H. J. Ann. 611 (1958) 57.

52. Bevan, T. H., Malkin, T. and Tiplady, J. M. J. Chem. Soc. 19573086.

53. Zervas, L. and Katsoyannis, P. G. J. Am. Chem. Soc. 77 (1955) 5351.

54. Zervas, L. Naturwiss. 27 (1939) 317.

55. Li, S. O. and Eakin, R. E. J. Am. Chem. Soc. 77 (1955) 1866.

56. Jones, E. E. and Lipkin, D. J. Am. Chem. Soc. 78 (1956) 2408.

57. Strid, L. Acta Chem. Scand. 13 (1959). In press.

58. Fölsch, G., Mellander, O. and Strid, L. Acta Chem. Scand. In press.

59. Losse, G. and Augustin, M. Chem. Ber. 91 (1958) 157.

60. Cipera, J. D. and Nicholls, R. V. V. Chem. \& Ind. London 195516.

61. Zervas, L., Winitz, M. and Greenstein, J. P. J. Org. Chem. 22 (1957) 1515.

62. Hanby, W. E., Waley, S. G. and Watson, J. J. Chem. Soc. 19503239.

Received May 13, 1959. 